

\title{
The contribution of economic science to brownfield redevelopment: a review
}

\author{
Joaquin Ameller, Jean-Daniel Rinaudo, Corinne Merly
}

\section{To cite this version:}

Joaquin Ameller, Jean-Daniel Rinaudo, Corinne Merly. The contribution of economic science to brownfield redevelopment: a review. Integrated Environmental Assessment and Management, 2020, 16 (2), pp.184-196. 10.1002/ieam.4233 . hal-02532209

\section{HAL Id: hal-02532209 \\ https://hal.science/hal-02532209}

Submitted on 4 Apr 2020

HAL is a multi-disciplinary open access archive for the deposit and dissemination of scientific research documents, whether they are published or not. The documents may come from teaching and research institutions in France or abroad, or from public or private research centers.
L'archive ouverte pluridisciplinaire HAL, est destinée au dépôt et à la diffusion de documents scientifiques de niveau recherche, publiés ou non, émanant des établissements d'enseignement et de recherche français ou étrangers, des laboratoires publics ou privés. 
Ameller, J., Rinaudo, J. D., \& Merly, C. (2020). The contribution of economic science to brownfield redevelopment: a review. Integrated Environmental Assessment and Management, 16(2), 184-196.

\title{
The contribution of economic science to brownfield redevelopment: a review
}

\author{
Ameller, J., Rinaudo, J. D., \& Merly
}

\begin{abstract}
Urban planners increasingly perceive Brownfield redevelopment (BFR) as a strategic priority. BFR not only allows suppressing some of the nuisances caused by derelict and contaminated lands, it also contributes to revitalizing dense urban areas and preventing the undesired effects of urban sprawl. This literature review paper analyses how economists have contributed to removing some of the barriers that prevent or restrict BFR. A first contribution was to demonstrate the economic benefits of BFR. Economists also contributed to the development of multidisciplinary decision support tools used to rank BFR projects in terms of long-term sustainability and social welfare. They also contributed to the design of institutional arrangements (including regulatory and economic instruments) that can facilitate the engagement of stakeholders in BFR projects. Our literature search combines the use of a standard and a systematic literature review to identify relevant papers scattered in very diversified publication outlets. We show that there is significant scope for better integration of economic analysis within the multidisciplinary mainstream of BFR literature, and provide pathways for future research.
\end{abstract}

\section{Keywords}

Brownfield redevelopment, contaminated site remediation, decision support tools, environmental valuation, cost benefit analysis.

JEL: O130, O180, Q510, Q560, Q580. 
Ameller, J., Rinaudo, J. D., \& Merly, C. (2020). The contribution of economic science to brownfield redevelopment: a review. Integrated Environmental Assessment and Management, 16(2), 184-196.

\section{INTRODUCTION}

Brownfield Redevelopment (BFR) is an issue of growing concern for urban planners and managers all over the world, especially in former industrialized regions of Europe, North America and in emerging economies (De Sousa 2004; Panagos et al. 2013; U.S. EPA 2016; U.S. EPA 2017; EEA 2018). More and more sites, which once supported intense economic or industrial activities, are now abandoned or underutilized. Their number is likely to increase as industrial activities continue to change and migrate to keep pace with technological development and globalization (Simmons 1998; Leigh and Coffin 2000; Adams et al. 2010; Payá Pérez and Rodríguez Eugenio 2018) ${ }^{1}$. Brownfields are often a source of nuisance for nearby residents (Gayer et al. 2000; Longo and Alberini 2006; Lesage et al. 2007), particularly in the case of contaminated sites (environmental and human health risks) or derelict buildings (risk of accidents, illegal occupation and crime). On the other hand, brownfields, which are frequently located close to settlements, offer genuine opportunities for urban development. Their redevelopment leads to the densification of urban areas, reinvigorates distressed neighborhoods and helps avoiding costs linked to urban sprawl (environmental and resource deterioration, extension of infrastructures, transportation costs, etc.). Federal, National and local governments are, therefore, trying to promote BFR to encourage commercial, residential or new industrial activities (De Sousa 2003; EC 2012; Schädler et al. 2012). However, soil and water contamination often require rehabilitation,

\footnotetext{
${ }^{1}$ A recent study covering 28 Europen Member states reveals the possible existence of around 2.8 million sites where polluting activities took/are taking place. Based on data reported by agencies of 16 European countries, 76000 new sites have been registered since 2014 (Payá Pérez and Rodríguez Eugenio 2018).
} 
Ameller, J., Rinaudo, J. D., \& Merly, C. (2020). The contribution of economic science to brownfield redevelopment: a review. Integrated Environmental Assessment and Management, 16(2), 184-196.

which may entail high remediation costs, complex administrative procedures and unexpected delays. The risks of future liability, stigma and uncertainty on remediation costs, all linked to the remaining contamination, have to be taken into account (Bartke 2011). These difficulties, in addition to frequent discrepancy between public and private interests, often represent important obstacles to BFR (Coffin and Shepherd 1998; Bartsch and Wells 2003; Whitney 2003; Paull 2008; BenDor et al. 2011; Spiess and De Sousa 2016).

This paper reviews how economic science, its underlying concepts and methodologies can help overcome some of these obstacles and facilitate BFR management. Economics is defined here as the social science which studies how individuals, businesses, governments, and other social groups make choices on allocating scarce resources to satisfy their wants and needs, trying to determine how these groups should organize and coordinate efforts to achieve maximum output and its equitable distribution. The relevant literature is scattered across an array of journals and produced by scientific communities with different disciplinary backgrounds. Therefore, for the sake of this review, we distinguish two main bodies of literature. The first brings together research involving multidisciplinary research groups. We refer to this multidisciplinary stream as sustainability assessment literature (SAL). It focuses on the development of decision support tools (DST) designed to guide redevelopers (Pediaditi et al. 2010). DST are generally used to assess and hierarchize alternative redevelopment projects, on the basis of a wide range of environmental, social and economic criteria. Huysegoms and Cappuyns (2017) realized a review specifically dedicated on these DST and found that the economic dimension is not systematically integrated; and when it is, it tends to rely on very simple and often qualitative methods and remains relatively peripheral.

The second body of literature is drawn from a diverse community of applied economists. In comparison to SAL, which tends to develop a holistic approach to BFR and 
Ameller, J., Rinaudo, J. D., \& Merly, C. (2020). The contribution of economic science to brownfield redevelopment: a review. Integrated Environmental Assessment and Management, 16(2), 184-196.

provide operational decision-making support, most contributions from the economic literature (EL) focus on very specific aspects of BFR, such as the valuation of specific health, environmental or social impacts or the design of economic instruments for policy intervention.. In addition, a number of economic papers focus on issues of economic methodology, where BFR is simply used as an example to test a methodological innovation. This EL emanates from different schools of thought in economics: environmental and health economics, which focuses primarily on the valuation of benefits that accrue from BFR; public economics, which evaluates budget-resource allocation efficiency; and institutional economics, which studies the interrelations between government bodies, society, private developers and landowners in BFR projects or policies. Thus, EL is scattered across very diverse specialist journals that cover domains, such as environmental and resource economics, public economics, urban and real estate economics and environmental management. This review aims helping to bridge gaps between SAL and EL scientific communities.

Overall, this paper has three main goals. First, it examines the level of cooperation between the two scientific communities (i.e. SAL and EL); second, it provides an overview of the literature that addresses the economics of brownfield redevelopment; third, it provides recommendations for future research on how to better integrate economics in multidisciplinary mainstream approaches of BFR. Thus, the novel features of this review are that it presents available knowledge and recent findings, but also proposes a holistic view of the applied multidisciplinary research that includes economic studies of BFR. To our knowledge, no other systematic review has the scope of the present study.

The paper is organized as follows: Section 2 introduces the main steps of the review methodology and the data sources used. Section 3 describes the concepts and methods found in the literature search. Section 4 discusses key findings and recommends directions for future 


\section{This is a pre-print version of :}

Ameller, J., Rinaudo, J. D., \& Merly, C. (2020). The contribution of economic science to brownfield redevelopment: a review. Integrated Environmental Assessment and Management, 16(2), 184-196.

research. Lastly, section 5 concludes with a general comment on the state of the art in managing BFR and the opportunities to integrate scientific efforts. 
Ameller, J., Rinaudo, J. D., \& Merly, C. (2020). The contribution of economic science to brownfield redevelopment: a review. Integrated Environmental Assessment and Management, 16(2), 184-196.

\section{MATERIAL AND METHOD}

Our research was conducted using two literature review coverage strategies: standard (pivotal) and systematic (representative) (Cooper 1988). We first conducted a standard review that consisted of identifying key papers that were important in terms of the scope of our review. Most of those important papers were produced by a limited number of prolific authors and published in a limited number of journals (Lin et al. 2019). We then worked backwards to review the references cited in those papers and forwards to examine articles that later referred to them (Webster and Watson 2002).

We then conducted a systematic review aiming to embrace a representative sample of the literature. In this section, we define the scope of the literature review. Then, we describe and justify the methodology used for the search criteria and the database developed. Lastly, we present the criteria used to organize and classify the literature that we chose to include in the database.

\section{Scope of the review}

The scope of the literature review presented in this paper is determined by the thematic issue under investigation (brownfield redevelopment) and the disciplinary perspective (economics). Brownfields are defined as "sites that have been affected by the former uses of the site and surrounding land, are derelict or underused, may have real or perceived contamination problems, are mainly in developed urban areas and require intervention to bring them back to beneficial use" (Oliver et al. 2005). Redevelopment refers to the complete intervention process that leads to a new land use. Brownfield redevelopment includes 
Ameller, J., Rinaudo, J. D., \& Merly, C. (2020). The contribution of economic science to brownfield redevelopment: a review. Integrated Environmental Assessment and Management, 16(2), 184-196.

different kinds of cleanup or rehabilitation works, as well as the realization of future land-use projects. The process may involve a broad range of studies, including contamination and risk assessments, environmental and suitability tests and choice of remediation technologies. As far as the disciplinary perspective is concerned, we only focus on studies that address at least one economic dimension of BFR at project or policy level.

\section{Overview of the methodology used in the systematic review}

A systematic review, compared to a standard review, requires a sample of methodically chosen studies (Hunt 1997). The method we used for the systematic review in this study comprises three main analytical steps: 1) Constructing the publications database; 2) Selecting relevant publications; and 3) Screening and analysis of selected papers. Our main source of data was the Web of Science database (WoS). We chose to focus on literature published in scientific journals ${ }^{2}$. The last database searches were conducted in August 2019.

\section{Selection of keywords to construct the database}

In step 1, we began by selecting keywords. A simple search with the keywords "brownfields", "redevelopment" and "economic" generated a very limited number of results (57). This was unexpected given the number of relevant papers identified within the standard review. Hence, we increased the number of keywords in order to generate a broader sample of results. Four groups of keywords were used in the search (Figure 1). Group (1) comprises

\footnotetext{
${ }^{2}$ By strictly focussing on papers referenced in WoS we not only exclude book chapters and conference proceedings but also papers published in professional journals and other types of grey literature. This means that we probably missed interesting contributions, but we assumed that the most significant results would have been mentioned by the authors in their published papers.
} 
Ameller, J., Rinaudo, J. D., \& Merly, C. (2020). The contribution of economic science to brownfield redevelopment: a review. Integrated Environmental Assessment and Management, 16(2), 184-196.

five keywords related to the physical object under study, which in literature is referred to using various keywords including "brownfields", "contaminated land", "contaminated sites", "derelict sites" or "vacant sites". Group (2) comprises six keywords used by authors to describe the redevelopment process ("redevelopment", "reuse", "remediation", "restoration", "regeneration" and "reconstruction"). Two additional groups of keywords were identified in relation to the disciplinary dimension. Group (3) is composed of keywords depicting sustainability assessment approaches and the corresponding Decision Support Tools. The keywords in group (4) refer to the different concepts and methods used in economic science (see annex 1). Group 4 was subdivided as follows: the valuation of BFR benefits (sub-group 4.1); resource allocation efficiency (sub-group 4.2); institutional set-up, including incentives, economic instruments, regulation, etc. (sub-group 4.3); and negotiation analyses (subgroup 4.4). All selected keywords were drawn from the articles identified in the preliminary standard literature search.

Figure 1: Groups of keywords used to identify the targeted literature and number of papers identified with successive combinations of keywords. 
Ameller, J., Rinaudo, J. D., \& Merly, C. (2020). The contribution of economic science to brownfield redevelopment: a review. Integrated Environmental Assessment and Management, 16(2), 184-196.

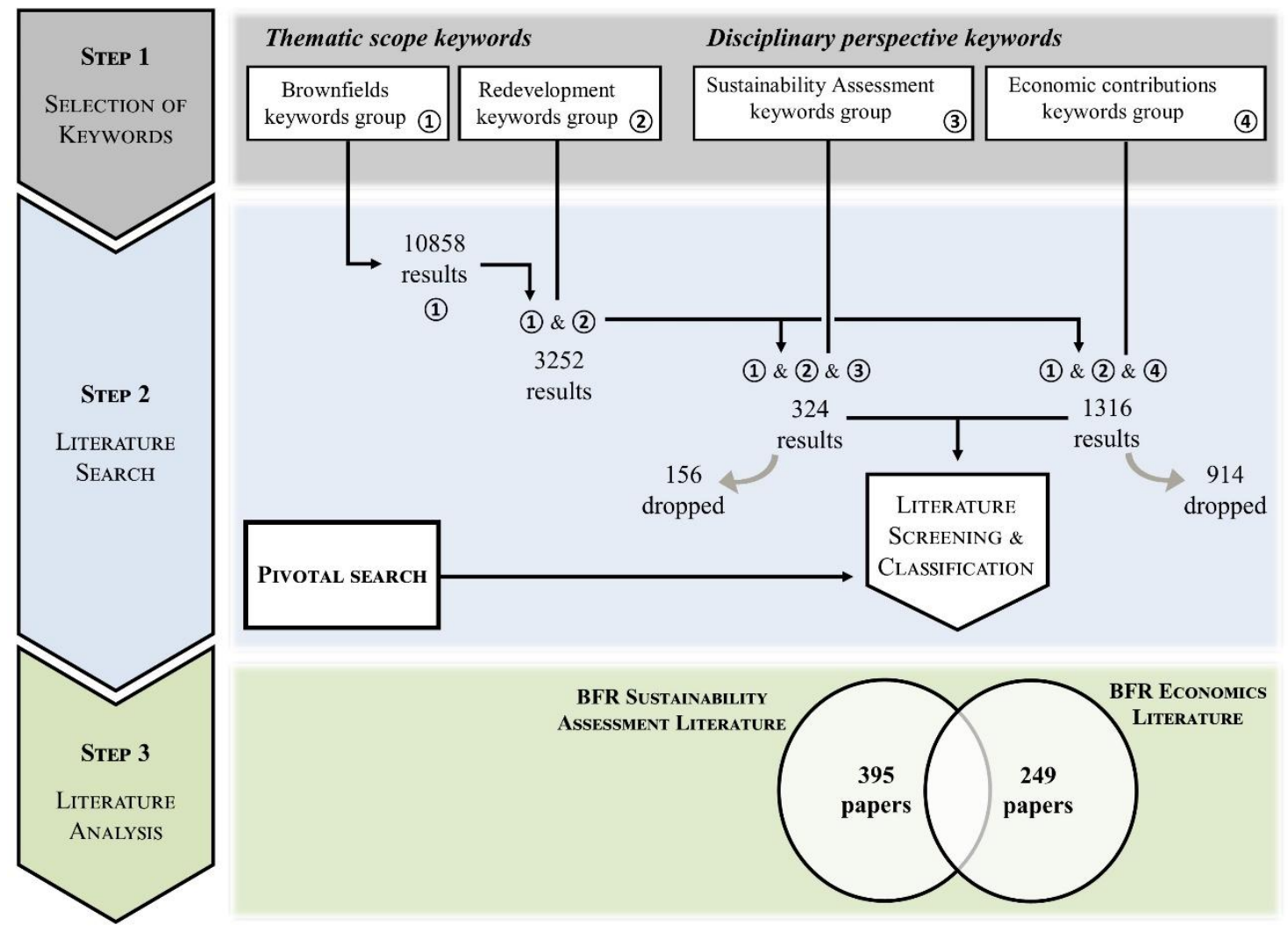

\section{$\underline{\text { Selection of relevant publications }}$}

In step 2, we screened (based on abstract reading) the contents of the two groups of articles identified in the search (EL and SAL). This selection was conducted as follows.

Regarding the Economic Literature, we only retained papers applying a theoretical framework, concepts, methods or tools that were clearly related to one of the domains of economic science (e.g. environmental economics, urban economics, real estate economics, health economics, political economy, public economics, etc.). We discarded papers that were neither investigating a clearly defined economic question nor producing new knowledge on an economic issue related to BFR. Many were only mentioning the economic dimension of BFR in the introduction or conclusion; many others were only dealing with technology costs. Hence, out of 1316 results, only 137 were retained (10.4\%). 
Ameller, J., Rinaudo, J. D., \& Merly, C. (2020). The contribution of economic science to brownfield redevelopment: a review. Integrated Environmental Assessment and Management, 16(2), 184-196.

Regarding the SAL, we discarded papers that were not including any economic indicator (qualitative or quantitative) in the sustainability assessment methodology. The final selection maintains 148 of the 324 papers identified with the keywords search. Additionally, we added 196 papers originally found with EL keywords, but which after screening and classification corresponded to SAL criteria. SAL presents very diverse tools and methodological approaches to compare and prioritize BFR options, for example, GIS based multi-criteria analysis, sustainability indicators, integrated assessments, and other modelling approaches.

The selection based on the systematic review was complemented by papers identified with the standard pivotal review and which had not been found with the keywords search. Hence, we added 112 economic papers to the EL selection and 50 papers to the SAL selection. Altogether, the final database comprise 557 papers, 249 EL papers, 395 SAL papers, and 87 papers dealing both with economic and sustainability aspects (which does not mean that they all integrate the economic contributions reviewed in the paper).

It is worth noting that plenty of papers were identified with the classical (pivotal) review. The systematic review allowed identifying 414 papers which would have been missed otherwise.

Step 3 involved analysis and classification of the 557 selected papers (full references are available in the supplemental material). We first summarized the main contribution of each paper in a few words or sentences. Based on that first analysis, a typology of contributions was developed and all papers subsequently recoded using that typology. The results are presented in a database that can be used by readers willing to investigate a specific issue (supplemental material). 
Ameller, J., Rinaudo, J. D., \& Merly, C. (2020). The contribution of economic science to brownfield redevelopment: a review. Integrated Environmental Assessment and Management, 16(2), 184-196.

\section{RESULTS}

\section{Sustainability Assessment Literature (SAL)}

This literature mainly includes papers on the development of decision support tools, which assess and compare the sustainability of various BFR projects or management options. In these papers, sustainability is defined by environmental, social and economic criteria. It is frequently assessed using a multi-criteria analysis (MCA) (Hou and Al-Tabbaa 2014) and involves multidisciplinary research. The economic criterion is not seen as an overarching factor, but is considered alongside environmental and social criteria. This approach has led to the development of many decision support tools, designed to facilitate the identification of possible trade-offs between the three dimensions (Bartke and Schwarze 2015). MCA uses a wide spectrum of qualitative and/or quantitative criteria, which are weighted according to expert knowledge or stakeholders' needs (Rizzo et al. 2015; Bartke et al. 2016). MCA methodologies are flexible and the choice of criteria can be adapted to the particular requirements of case studies. However, there is a drawback: selecting and weighting criteria is challenging because it involves a degree of subjectivity. In other words, representativeness and transparency can be problematic (Wedding and Crawford-Brown 2007; Doick et al. 2009; Bardos et al. 2011).

In most cases, SAL considers BFR decision-making processes at two different scales. At (local) site scale, DST are often designed to select the most appropriate remedial technology (Carlon et al. 2007; Critto and Agostini 2009; Li et al. 2010; Sorvari and Seppälä 2010; Beames et al. 2015; Chen et al. 2016; Song et al. 2018). At regional scale, the goal is to set priorities for the redevelopment of a portfolio of contaminated sites. We illustrate these approaches with the examples provided in Table 1. 


\section{This is a pre-print version of :}

Ameller, J., Rinaudo, J. D., \& Merly, C. (2020). The contribution of economic science to brownfield redevelopment: a review. Integrated Environmental Assessment and Management, 16(2), 184-196.

Table 1: Selected examples of sustainable assessment decision support tools

\begin{tabular}{|c|c|c|}
\hline Scale & Case Study & $\begin{array}{c}\text { Supplemental } \\
\text { Material }\end{array}$ \\
\hline $\begin{array}{l}\text { Site } \\
\text { level }\end{array}$ & $\begin{array}{l}\text { Rosén, et al.(2015) developed SCORE, a tool based on Multi-Criteria Decision } \\
\text { Analysis (MCDA) designed to provide a flexible and transparent sustainability } \\
\text { assessment of alternative BFR scenarios for a contaminated site. This DST integrates } \\
\text { qualitative and quantitative indicators to account for social and environmental } \\
\text { criteria, a cost-benefit analysis to compare the economic performance of scenarios } \\
\text { and a Monte-Carlo simulation to address uncertainty issues. }\end{array}$ & $\begin{array}{l}\text { Number of } \\
\text { papers: } 129 \\
(\text { Select } S A L=1 ; \\
\text { Site-Specific }=1)\end{array}$ \\
\hline $\begin{array}{l}\text { Regional } \\
\text { level }\end{array}$ & $\begin{array}{l}\text { Pizzol et al.(2016) developed TIMBRE, a prioritization tool that identifies which } \\
\text { brownfields are better suited for successful redevelopment. The evaluation } \\
\text { methodology, tested on a portfolio of } 252 \text { sites in the Czech Republic, incorporates } \\
\text { economic, social and environmental criteria. The authors identified success factors } \\
\text { (e.g. education index, land value, transport links, contamination) and indicators (e.g. } \\
\text { percentage of people that have had a higher education, average price, proximity to } \\
\text { highways, contamination status) to represent the three dimensions: local } \\
\text { redevelopment potential (economic), site attractiveness and marketability (social) } \\
\text { and environmental risks. The weight and aggregation of indicators make it possible } \\
\text { to rank sites andidentify the most promising. }\end{array}$ & $\begin{array}{l}\text { Number of } \\
\text { papers: } 42 \\
(\text { Select } \mathrm{SAL}=1 ; \\
\text { Regional }=1 \text { ) }\end{array}$ \\
\hline
\end{tabular}

\section{How does economics contribute to BFR? (EL)}

EL covers three broad groups of papers, which focus on the following issues:

- the valuation of BFR benefits, which includes non-financial benefits (e.g. environmental, social and health); Number of papers: 96 (In supplemental material, select EL=1; Monetary valuations $=1$ ).

- economic appraisal of BFR projects, which takes into account a wide range of costs and benefits, assessed in monetary terms (e.g. cost-benefit or cost-effectiveness analysis); Number of papers: 52 (Select EL=1; Project desirability=1). 
Ameller, J., Rinaudo, J. D., \& Merly, C. (2020). The contribution of economic science to brownfield redevelopment: a review. Integrated Environmental Assessment and Management, 16(2), 184-196.

- the assessment of policy instruments and institutional arrangements, which may foster stakeholder's engagement and investment in BFR. Number of papers: 109 (Select EL=1, Institutional approaches $=1)$.

\section{Valuation of BFR benefits}

Economics has an important contribution to make when it comes to the evaluation of BFR benefits. Herein financial benefits can be distinguished from non-financial benefits: the former mainly consist on the profits and tax revenues generated by BFR projects; and the non-financial benefits involve social welfare by improving environmental, health and social factors. The monetary value of these benefits can be estimated, aggregated and compared. The literature primarily considers three types of benefits: economic (private profit, tax revenues), social (employment, quality of life) and environmental (De Sousa 2002; Turvani and Tonin 2008; Bardos et al. 2016). It often makes a distinction between the benefits derived from the cleanup of contaminated sites and site reuse (new activity). As far as cleanup is concerned, EL attributes an economic value to improvements in soil, air and water quality, by examining how improvements reduce human health risks, enhance ecosystem services, provide new amenities for residents, reduce crime and stigma, as well as boost the value of surrounding property. As far as site reuse is concerned, EL considers direct economic benefits, such as tax revenues, job creation (Jenkins et al. 2006; Paull 2008), as well as indirect financial benefits, for example, containing urban sprawl. Indeed, the redevelopment of BFs may reduce energy consumption, transport costs, $\mathrm{CO}_{2}$ emissions and the need for new public infrastructure.

Figure 2 shows how BFR benefits can be classified according to the EL surveyed in this paper. 
Ameller, J., Rinaudo, J. D., \& Merly, C. (2020). The contribution of economic science to brownfield redevelopment: a review. Integrated Environmental Assessment and Management, 16(2), 184-196.

Figure 2: Main benefits of brownfield redevelopment

\begin{tabular}{|c|c|c|c|c|}
\hline \multirow{2}{*}{\begin{tabular}{l} 
RedeVElopme \\
Process \\
\hdashline--7 \\
$\vdots$ \\
$\vdots$ \\
$\vdots$
\end{tabular}} & MENT & $\begin{array}{l}\text { Removal of health \& } \\
\text { environmental risks }\end{array}$ & $\begin{array}{l}\text { Development of new } \\
\text { activities }\end{array}$ & $\begin{array}{l}\text { Redevelopment of } \\
\text { adjacent neighborhoods }\end{array}$ \\
\hline & $\begin{array}{l}\text { Diagnosis } \\
\text { Soil \& water } \\
\text { sample analysis }\end{array}$ & $\begin{array}{l}\text { Soil decontamination. } \\
\text { Deconstruction of derelict } \\
\text { buildings. Removal of } \\
\text { toxic waste }\end{array}$ & $\begin{array}{l}\text { Commercial \& industrial, } \\
\text { housing. Development of } \\
\text { vegetation, parks, } \\
\text { recreational sites }\end{array}$ & $\begin{array}{l}\text { Transport infrastructures, } \\
\text { public \& commercial } \\
\text { facilities; new housing } \\
\text { programs }\end{array}$ \\
\hline & BF assessment & BF clean-up & BF redevelopment & Urban regeneration \\
\hline \multirow{5}{*}{\begin{tabular}{l} 
RedeVElop \\
ECONOMIC \\
Benefits \\
\hdashline-- \\
$\vdots$ \\
$\vdots$ \\
$\vdots$ \\
$\vdots$ \\
$\vdots$
\end{tabular}} & MENT & Suppression of nuisances & New sources of wealth & Other positive externalities \\
\hline & & $\begin{array}{l}\text { Reduced pollution of ground- } \\
\text { water, reduction of cost of }\end{array}$ & $\begin{array}{l}\text { Commercial \& industrial } \\
\text { investment }\end{array}$ & $\begin{array}{l}\text { Abatement of negative } \\
\text { stigma }\end{array}$ \\
\hline & & $\begin{array}{l}\text { water supply } \\
\text { Regeneration of biodiversity }\end{array}$ & $\begin{array}{l}\text { Development of vegetation, } \\
\text { parks, recreational sites }\end{array}$ & $\begin{array}{l}\text { Profit of existing } \\
\text { infrastructure and local }\end{array}$ \\
\hline & DIRECT & $\&$ related provision of & Recycling of existing & services \\
\hline & $\begin{array}{l}\text { ON-SITE } \\
\text { BENEFITS }\end{array}$ & ecosystem services & $\begin{array}{l}\text { resources (Soil, building } \\
\text { materials) }\end{array}$ & $\begin{array}{l}\text { Increased market land value } \\
\text { in former BF area }\end{array}$ \\
\hline \multicolumn{5}{|c|}{ L - } \\
\hline \multirow[t]{2}{*}{$\begin{array}{l}i \\
i \\
i \\
i\end{array}$} & $\begin{array}{l}\text { INDIRECT } \\
\text { OFF-SITE } \\
\text { BENEFITS }\end{array}$ & $\begin{array}{l}\text { Management of } \\
\text { environmental risks } \\
\text { Reduced health risks for }\end{array}$ & \multirow{2}{*}{$\begin{array}{l}\text { For residents: } \\
\text { Increased quality of life, job } \\
\text { and business opportunities, } \\
\text { recreational possibilities }\end{array}$} & $\begin{array}{l}\text { Urban densification, avoided } \\
\text { urban sprawl and related } \\
\text { infrastructure costs }\end{array}$ \\
\hline & & nearby residents & & Reduction of energy \\
\hline i & & $\begin{array}{l}\text { Reduced crime risk after } \\
\text { removal of derelict buildings }\end{array}$ & \multirow{2}{*}{$\begin{array}{l}\text { For municipalities: } \\
\text { Increased economic activity, } \\
\text { increase added value and tax } \\
\text { income }\end{array}$} & $\begin{array}{l}\text { consumption, pollution \& } \\
\text { transport costs }\end{array}$ \\
\hline $\begin{array}{l}1 \\
1 \\
1\end{array}$ & & $\begin{array}{l}\text { Increased attractiveness and } \\
\text { property price of surrounding } \\
\text { areas }\end{array}$ & & $\begin{array}{l}\text { Attraction of further } \\
\text { investment and technologies }\end{array}$ \\
\hline
\end{tabular}

Two major methodological approaches are used in environmental economics to assess the economic benefits of BFR (Turvani and Tonin 2008). Stated preference methods directly elicit individuals' preference and demand for BFR benefits, usually through surveys, using the contingent valuation method or the discrete choice experiment approach. These methods are used to estimate individuals' willingness to pay for environmental, health and other social improvements associated with BFR. By contrast, revealed preference methods (2) analyze how BFR affects the market value of goods (in particular, the housing market). In other words, they are used to estimate the impact that nuisances linked to BFs may have on the value of goods (or the benefits associated with eradicating the nuisance). The hedonic pricing method has been widely used to assess the impact of BFs on property values. Table 2 presents 


\section{This is a pre-print version of :}

Ameller, J., Rinaudo, J. D., \& Merly, C. (2020). The contribution of economic science to brownfield redevelopment: a review. Integrated Environmental Assessment and Management, 16(2), 184-196.

a brief description and provides an illustrative example of the economic valuation methods applied to BFR found in the literature. 


\section{This is a pre-print version of :}

Ameller, J., Rinaudo, J. D., \& Merly, C. (2020). The contribution of economic science to brownfield redevelopment: a review. Integrated Environmental Assessment and Management, 16(2), 184-196.

Table 2: Economic methods for the valuation of BFR benefits

\section{Method}

Concept

Illustrative case study

Supplemental

Material

Revealed preferences

Hedonic Pricing The hedonic pricing method assumes that residents are willing to pay more to live in areas with fewer risks or nuisances. Consequently, property markets capitalize on the impacts of BFR an how it affects adjacent land use (Farber 1998). Using real data from property transactions, the method identifies the properties' characteristics, obtains estimates of the implicit price of each characteristic and develops econometric regression models to explain observed property marke prices as a function of their intrinsic and locational characteristics (Palmquist 1984).

Avoided costs This approach consists in identifying and measuring the costs and efforts avoided by redeveloping brownfields in comparison to an alternative scenario. Given that many brownfield are located in dense urban areas, most avoided costs (i.e. benefits) are related to the impacts of urban sprawl (see also Mashayekh et al., 2012).
Neupane and Gustavson (2008) carried out a hedonic pricing valuation method to evaluate the property value effects of the presence of the Tar Ponds and Coke Ovens, former industrial sites in Nova Scotia, Canada. Presence of brownfields had a significan negative effect on the value of residential property, estimating a total loss of \$CDN 36 million. Notably, the effect was localized within a few hundred meters of the sites.

De Sousa (2002) estimated the BFR benefits of preserving agricultural and, as well as avoiding transport costs and externalities, in comparison to the development of greenfield sites in Toronto, Canada. The author's findings demonstrate that including avoided costs and other BFR benefits in the analysis enhances the economic viability of BFR.
Number of papers: 35 (Select EL=1;

Hedonic pricing $=1$

Number of papers: 6

(Select EL=1;

Avoided Costs $=1$ )

\section{Stated preferences}

Contingent

Valuation

Choice

Modeling
The approach consists in directly asking individuals to express their willingness to pay for an environmental change. As far as BFR is concerned, a Contingent Valuation Method (CVM) survey could be used to elicit public preferences for remediating a specific contaminated site (Tyrväinen and Väänänen 1998; Simons and Winson-Geideman 2005; See for example Simons and Saginor 2010).

Choice-modeling experiments (also known as conjoint analysis) entail designing hypothetical scenarios with a number of attributes, including a cost reference. Participants are then asked to choose the scenarios. In addition to valuing their preferences for a certain change, this method can be used to ascertain stakeholders' preferences regarding the possible attributes (See
Damigos and Kaliampakos (2003) conducted a CVM to assess the preferences of the residents in Athens, Greece, regarding the redevelopment of an abandoned quarry located in the center of the city. Results allowed authors to quantify public preferences for land reclamation and the construction of a park with underground parking.

Alberini et al. (2007) used conjoint choice questions to estimate the value of statistical life (VSL) regarding the reduction of mortality risks as a result of remediation policies in four cities in Italy. The survey allowed the authors to quantify the preferences for these remediation
Number of papers: 7

(Select EL=1;

Contingent valuation=1)

Number of papers: 13 (Select EL=1; 


\section{This is a pre-print version of :}

Ameller, J., Rinaudo, J. D., \& Merly, C. (2020). The contribution of economic science to brownfield redevelopment: a review. Integrated Environmental Assessment and

Management, 16(2), 184-196.

Strazzera et al. 2010). policies on the basis of income and demographic characteristics. Thus, the authors were able to identify preferences for immediate, future and permanent reductions in mortality risks.
Choice modelling=1) 
Ameller, J., Rinaudo, J. D., \& Merly, C. (2020). The contribution of economic science to brownfield redevelopment: a review. Integrated Environmental Assessment and Management, 16(2), 184-196.

\section{Comparing the economic performance of alternative projects or policies}

Public economics also has a major contribution to make to BFR. It can be used to assess the efficiency of public resource allocation, through economic appraisal methods, such as Cost-Benefit-Analysis (CBA) or Cost-Effectiveness-Analysis (CEA). CBA and CEA are used to evaluate, compare and rank the outcome of alternative policy interventions or projects. Cost-Benefit Analysis (CBA) identifies and aggregates the financial, social and environmental benefits of a BFR project or policy, which are then compared to its implementation costs (Hanley 2001). If the difference between benefits and costs is positive, the project is economically desirable. The higher the net benefit, the more viable the project. Hence, CBA requires a systematic assessment of all costs and benefits relating to BFR projects (using the methods described in subsection 0). In the context of BFR projects, conducting a thorough cost-benefit analysis can be challenging because it can be difficult to account for and quantify all the costs and benefits, and its distribution among the stakeholders (Rinaudo and Loubier 2005).

A recent example of CBA applied to BFR was conducted in Sweden by Volchko et al. (2017). They assessed the redevelopment of four different alternatives of copper recovery projects in Köpmannebro, a contaminated site formerly used to produce impregnated telegraph poles. All options involved the same conventional "excavation and disposal" remediation method. They differed in terms of the pre-treatment approaches and the other metal recovery procedures. The study considered internal project benefits, for example, improved health, provision of ecosystem services and remediation costs, as well as the negative impact of the remedial action, including impaired health and reduced ecosystem services. Other positive and negative externalities were also considered. Thus, findings allowed the authors to identify the best remedial option for two different scenarios. For more examples, see Huysegoms et al., 2018; Lavee et al., 2012; Rinaudo and Aulong, 2014; Söderqvist et al., 2015. 
Ameller, J., Rinaudo, J. D., \& Merly, C. (2020). The contribution of economic science to brownfield redevelopment: a review. Integrated Environmental Assessment and Management, 16(2), 184-196.

The Cost-Effectiveness Analysis aims to identify the BFR alternative that minimizes cost, while meeting specific objectives as effectively as possible (Döberl et al. 2013). Costs are considered in monetary terms and effectiveness is assessed in quantitative non-monetary terms. In this regard, CEA makes it possible to allocate resources by selecting the policy that achieves the best value at lower cost. A good illustration of this approach is given by Schädler et al. (2011). They developed an integrated assessment method to evaluate redevelopment options (including remediation concerns) for different plots of land at a 113-hectare 'mega-site' in the city of Potsdam, Germany. Their approach included an assessment of (i) subsurface remediation and site preparation costs, (ii) market-orientated economic appraisal and (iii) the expected contribution of future land use to sustainable development objectives. The methodology made it possible to combine the first and second elements and express them in monetary terms: remediation costs, land-market value estimation and market value reduction. Authors then compared this combined monetary criteria with a third element (an aggregation of sustainable development indicators). Although this example goes beyond a classic performance-overinvestment CEA, the findings allowed the authors to identify the most cost-effective combination of revitalization options for the site in terms of economic and sustainability criteria. Other examples are presented by Day et al., 1997; Gomez-Navarro and Garcia-Melon, 2011.

\section{Studying the economic relations between the institutional frameworks and stakeholders' behavior}

The third group of economic papers identified in the survey look at how institutional set-ups and stakeholders' interests drive actual BFR decision-making. Unlike public economic approaches, where it is assumed that decisions are driven by the general interest, this body of literature reveals that decisions are shaped by a number of stakeholders with different interests: landowners, developers, financial institutions, endusers, community groups and different levels of government (e.g. municipalities, regional and national 
Ameller, J., Rinaudo, J. D., \& Merly, C. (2020). The contribution of economic science to brownfield redevelopment: a review. Integrated Environmental Assessment and Management, 16(2), 184-196.

agencies). Thus, this literature examines different actors' economic behavior and how they interact through negotiation processes in relation to BFR. It explores the role of institutions, defined in a broad sense ${ }^{3}$, in terms of the economic behavior that drives BFR projects. This literature investigates how different policy instruments can help remove the obstacles to brownfield redevelopment. These include liability in terms of inherited pollution risks, regulatory burdens and associated transaction costs, uncertain evolution of cleanup standards and funding mechanisms (BenDor et al. 2011). In this regard, Adams and his colleagues (2001) show that BFR is hindered by certain factors that affect the land market (transaction costs, limited supply and demand, imperfect information and externalities). In response, public authorities offer incentives and adopt regulatory policies to foster BFR. For instance, policymakers may provide financial incentives (subsidies) to encourage private investors. For this purpose, direct policy instruments can be used, including: (i) Subsidies (e.g. to facilitate contamination assessments or decontamination expenses); (ii) Minimization of liability burdens and uncertainties linked to future cleanup requirements and community complaints; (iii) Alleviation of transaction costs by simplifying administrative procedures and requirements. On the other hand, indirect policies can also be used to make brownfields more attractive economically: (iv) Taxing greenfield developments; (v) Developing public infrastructure and facilities to improve the real estate market in the area (e.g. public transport, recreation, education, culture). Table 3 presents some examples of studies on policy effectiveness.

Overall, lessons learned from this literature are context-specific, conditioned by the specific legal and institutional framework of each case study. Therefore, it is difficult to apply the conclusions to other contexts. We also found that a large number of studies were based on ex-post analysis. These frequently involved a statistical analysis of time series, in an attempt to provide statistical evidence and reveal the impact of various policy instruments or institutional set-ups. We found very few ex-ante studies, which assess the effect of

\footnotetext{
${ }^{3}$ Institutions are understood as "the written and unwritten rules, norms and constraints that humans devise to reduce uncertainty and control their environment” (Menard and Shirley, 2005, p. 1).
} 


\section{This is a pre-print version of :}

Ameller, J., Rinaudo, J. D., \& Merly, C. (2020). The contribution of economic science to brownfield redevelopment: a review. Integrated Environmental Assessment and Management, 16(2), 184-196.

different policy instrument scenarios, using micro-economic models or experimental approaches. Some leads for future research include the use of game theory models to represent courses of action (Samsura et al. 2010; Glumac et al. 2011; Blokhuis et al. 2012; Glumac et al. 2015) or accounting for the divergent interests of stakeholders to analyze decision-making (Yousefi et al. 2007; Walker et al. 2010; Yousefi et al. 2010). 
Ameller, J., Rinaudo, J. D., \& Merly, C. (2020). The contribution of economic science to brownfield redevelopment: a review. Integrated Environmental Assessment and Management, 16(2), 184-196.

Table 3: Illustrative examples of studies to assess the effectiveness of policymaking

Institutional framework component
Case Study
- Subsidies

- Taxes
Adams, Disberry et al. (2000) interviewed a number of landowners and experienced organizations in order to assess the efficacy of fiscal measures in four cities in the UK. The authors conclude that taxes and subsidies do provide incentives for developers to invest, but there are certain nuances when it comes to their acceptance: carefully designed taxes may be appropriate in markets where there is a strong demand, but development can spill onto greenfield sites, despite the existence of brownfield alternatives. Fiscal penalties might result inappropriate whereas financial support incentives seem to be consistently plausible measures.
- Liability relief

- Direct financial incentives

- Regulatory relief
Alberini, Longo et al. (2005) gathered information in a survey from a sample of developers and real estate professionals at an international conference in Cannes, France. Following a conjoint choice experiment, results suggested that developers are positively responsive to liability reliefs, financial support and regulatory flexibility. In addition, the authors observed that developers highly appreciate transport facilities and do not discriminate against prior contamination once a given site has been remediated.
- Reimbursement of study costs

- Requirement of public hearings

- Protection against further liabilities for cleanup costs

- Protection against third party liabilities

- Subsidies for construction costs.
Wernstedt et al. (Wernstedt et al. 2006) conducted a nationwide mail survey of private developers in the USA to identify the most effective public incentives for fostering private investment in BFR. Using a conjoint analysis (i.e. choice model experiment), the authors found that protection from third party liability is highly effective. They also revealed that protection from cleanup liability and relief from public hearing requirements were important. Furthermore, the developers' experience is likely to play a role in their acceptance of the different policies.
- Liability relief

- Public disclosure
Blackman et al. (2010) analyzed real data from Oregon's database in order to assess the effectiveness of voluntary cleanup programs (VCP). Hence, 33\% of 1534 sites participated in VCPs, whereas $8 \%$ took independent pathways and $59 \%$ participated in neither. Authors carried a multinomial probit regression, which revealed that liability relief incentives, a feature of Oregon's voluntary programs, were an effective incentive to clean highly contaminated sites. They observed that regulatory pressure, such as the public disclosure of lists of contaminated sites, also encouraged participation.

Eckerd and Heidelberg (2015) conducted a time-series logistic regression with data from 6932 brownfield sites across the USA's states. The authors conclude that tax credit mechanisms seem to encourage private investment. However, they argue that some direct incentives may simply make profitable projects more attractive, while less favored sites remain sidelined. In addition, of all the liability relief instruments, only insurance facilities seem to significantly encourage private involvement.

Supplemental Material: Taxes (31 papers); Subsidies (32); Liabilities (40); Stakeholders attitudes or perceptions (55). 
Ameller, J., Rinaudo, J. D., \& Merly, C. (2020). The contribution of economic science to brownfield redevelopment: a review. Integrated Environmental Assessment and Management, 16(2), 184-196.

\section{Links between the two literatures $(S A L \& E L)$}

Interestingly, the two bodies of literature overlap, which suggests that the two scientific communities already interact. For instance, 196 papers identified with the search for economic keywords (Search EL) were ultimately attributed to SAL. Similarly, 52 papers identified with SA keywords were actually considered as part of the EL . The analysis of the publication outlets led to a similar conclusion: as shown in Table 4, a significant

number of selected papers were published in just five journals (119, which represents 21.36\%), and several journals publish both papers on EL and SAL. 
Ameller, J., Rinaudo, J. D., \& Merly, C. (2020). The contribution of economic science to brownfield redevelopment: a review. Integrated Environmental Assessment and Management, 16(2), 184-196.

Table 4: Analysis of results and journal outlets

\begin{tabular}{lcc}
\hline \multicolumn{1}{c}{ Main publication outlets } & SAL & EL \\
\hline Science of The Total Environment & 33 & 10 \\
Journal of Environmental Management & 27 & 17 \\
Sustainability & 13 & 10 \\
Journal of Cleaner Production & 15 & 8 \\
Environmental Science and Pollution Research & 14 & 1 \\
Journal of Urban Planning and Development & 9 & 8 \\
Environmental Management & 9 & 5 \\
Integrated Environmental Assessment and Management & 12 & 2 \\
Journal of Hazardous Materials & 10 & 1 \\
Land Use Policy & 2 & 10 \\
Landscape and Urban Planning & 7 & 3 \\
Economic Development Quarterly & 0 & 7 \\
Environment International & 7 & 0 \\
Journal of Environmental Planning and Management & 0 & 7 \\
Urban Forestry \& Urban Greening & 0 & 4 \\
\hline
\end{tabular}

\section{Secondary publication outlets}

Chemosphere, Environmental Science \& Policy, Human and Ecological Risk Assessment, International Journal of Environmental Research and Public Health, Journal of Soils and Sediments, Ecological Economics, Journal of Urban Planning and Development-ASCE, Water Air and Soil Pollution, Environment and Planning A, Environmental Engineering and Management Journal, Environmental Modelling \& Software, Environmental Science \&

Technology, International Journal of Life Cycle Assessment, Journal of Real Estate Research, Journal of The Institution of Water and Environmental Management, Journal of Urban Economics, Soil \& Sediment Contamination, Waste Management

\section{Other publication outlets}

Abstracts of Papers of the American Chemical Society, Building Research and Information, Ecological Engineering, Ecosystem Services, Environmental Health Perspectives,

Environmental Practice, Environmental Research, International Journal of Environment and Pollution, Journal of Environmental Economics and Management, Journal of Environmental

Radioactivity, Land Economics, Moravian Geographical Reports, Nuclear Energy-Journal of the British Nuclear Energy Society, Proceedings of the Institution of Civil Engineers-

Municipal Engineer, Risk Analysis, Urban Studies

Other journals

Total number of journals: 231

Table 5 presents the economic approaches and methodologies most commonly used in the SAL. We find that $22 \%$ of SAL studies include economic criteria (quantitative or qualitative). Monetary values are 
Ameller, J., Rinaudo, J. D., \& Merly, C. (2020). The contribution of economic science to brownfield redevelopment: a review. Integrated Environmental Assessment and Management, 16(2), 184-196.

frequently limited to the costs of remediation (engineering-economic approach), while economic methods and monetary valuations of benefits are poorly integrated (6\%). Similarly, methods involving the economic appraisal of projects and policies, such as CBA and CEA (3\% and 6\% respectively), as well as institutional orientated approaches (9\%) and economic behavior modeling approaches are relatively seldom used. Therefore, there is substantial scope for improving the integration of economic approaches in DST for sustainability assessments, particularly with regard to the economic assessment of BFR benefits.

Table 5: Papers in the SAL database that include economic analyses and methods

\begin{tabular}{|c|c|c|c|c|c|c|}
\hline SAL $(n=395)$ & Yes & No & Yes & No & & $\overline{\text { Yes }}$ \\
\hline Integration of economic approaches & 87 & 308 & $22 \%$ & $\mathbf{7 8 \%}$ & & \\
\hline Includes monetary valuations & 23 & 372 & $6 \%$ & $94 \%$ & Includes institutional economics approaches & 34 \\
\hline - Property values & 9 & 386 & $2 \%$ & $98 \%$ & - Taxes & 5 \\
\hline - Avoided costs & 1 & 394 & $0 \%$ & $100 \%$ & - Subsidies & 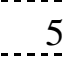 \\
\hline - Human health & 5 & 390 & $1 \%$ & $99 \%$ & - Liabilities & 11 \\
\hline - Environmental impacts & 5 & 390 & $1 \%$ & $99 \%$ & - Stakeholders attitudes/perceptions & 18 \\
\hline - Other benefits & 16 & 379 & $4 \%$ & $96 \%$ & - Other & 13 \\
\hline Includes valuation methods & 1 & 394 & $\mathbf{0 \%}$ & $100 \%$ & Decision support tools & . \\
\hline - Hedonic pricing & 1. & 394 & $0 \%$ & $100 \%$ & - Includes Cost-Benefit Analysis & $\cdots$ \\
\hline - Avoided costs & 0 & 395 & $0 \%$ & $100 \%$ & - Includes Cost-Efficiency Analysis & 22 \\
\hline - Contingent valuation & 0 & 395 & $0 \%$ & $100 \%$ & - MCA (Includes more than costs values) & 19 \\
\hline - Choice modelling & 0 & 395 & $0 \%$ & $100 \%$ & - MCA (Costs or qualitative economic criteria) & 45 \\
\hline
\end{tabular}

Table 5 displays percentages of papers in the SAL database that include economic analyses and methods.

\section{DISCUSSION}

\section{Different research postures in $S A L$ and $E L$}

The two bodies of literature surveyed in this paper deal with the economic dimensions of BFR in very different ways. The SAL mainly reports on the development of multidisciplinary operational methodologies, designed to support decisions that concern redevelopment at local or regional scales. The advantage of the methods proposed by SAL is their holistic approach, which encompasses the technical, environmental, health, 
Ameller, J., Rinaudo, J. D., \& Merly, C. (2020). The contribution of economic science to brownfield redevelopment: a review. Integrated Environmental Assessment and Management, 16(2), 184-196.

social and economic dimensions of BFR. The corollary is that each dimension is assessed using ad hoc methods and tools that may not fully exploit existing knowledge and methodologies geared to specific fields; for example, the economic impacts of BFR may be assessed based on expert judgement using semi-quantitative indicators, instead of using economic valuation methods. In contrast, EL is generally far more interpretative than prescriptive (with the exception of CBA and CEA studies). For instance, it highlights the processes that determine the nature and magnitude of the impact of BFR, rather than evaluating alternative BFR options. EL has a more fragmented approach to BFR. Most papers focus on relatively narrow issues (e.g. impact of BFR on property values), but adopt thorough and progressive approaches and go beyond the state of the art in the discipline. Overall, SAL and EL have very different research postures in terms of the trade-off between operational scope and advances in the disciplinary field.

Figure 3 presents the sub-groups of the literature (EL and SAL) in terms of their scale of application (local to global) and operational level (from conceptual level to decision support). This figure shows that Decision Support Tools are commonly applied at the site-specific scale to select remediation techniques. They are less frequently applied at regional scale to prioritize site development and remediation. In terms of development, CBA and CEA are operational economic tools that have been widely tested and applied in the economic literature. However, they are rarely or only partially applied in BFR. Indeed, simple CBA is sometimes performed to select remediation technologies on the basis of remediation costs, without taking the full valuation of benefits into account. Moreover, it is difficult to apply CBA to back up DST at a regional scale because only a few studies provide a monetary valuation of BFR benefits. When more literature on the monetary valuation of BFR benefits is available, it will be possible to conduct a full CBA on a broader scale. Lastly, studies that focus on policy instruments and stakeholders tend to be more applied when it comes to subjects beyond local site specificities. 
Ameller, J., Rinaudo, J. D., \& Merly, C. (2020). The contribution of economic science to brownfield redevelopment: a review. Integrated Environmental Assessment and Management, 16(2), 184-196.

Figure 3. Analysis of EL \& SAL



\section{Gaps and directions for future research in $E L$}

Our review of EL revealed several gaps in current research, which should be addressed by future research projects. They include:

- The monetary valuation of BFR impacts. Most papers use hedonic pricing methods, which assess the impact of BFR alternatives on property value. This approach provides results that are easy to communicate to stakeholders, but it fails to indicate how the different social, environmental, health and other impacts contribute to changing property values. Very few studies actually examine the monetary values of each of these benefits separately. Also, most BFR benefit studies focus on specific sites and we did not find attempts to assess the benefits that could be generated by a portfolio of projects at metropolitan or regional level. This is an area where additional research is needed. 
Ameller, J., Rinaudo, J. D., \& Merly, C. (2020). The contribution of economic science to brownfield redevelopment: a review. Integrated Environmental Assessment and Management, 16(2), 184-196.

- The economic valuation of ecosystem services associated with the redevelopment of brownfields into green spaces or soft reuse (e.g. $\mathrm{CO}_{2}$ storage, storm water management, soil biodiversity, etc.). We did not find a single study on the evaluation of the indirect costs associated with the loss of ecosystem services following the commercial, residential or industrial redevelopment of abandoned sites reclaimed by nature. Studies of this kind are needed to calculate the true benefits of turning brownfields into green spaces, which are independent from the inherent rise in property values for nearby residential areas.

- We found that most case studies reported in the EL focus on redevelopment options (residential, commercial, industrial, parks, etc.) that derive an economic value from human presence. Many BF sites are actually located within large industrial complexes, where redevelopment projects involving people are not feasible because of industrial constraints (noise, pollution and risk of explosion). Alternative uses are the only possible options on these sites, for example, photovoltaic production, biomass production or ecological compensation. The economic value of BFR for these uses should be investigated.

- $\quad$ BFR's impact on mitigating urban sprawl. Many papers claim that BFR reduces urban sprawl, limiting the loss of agricultural land and natural resources, as well as the cost of developing infrastructure. However, the claims are generally qualitative. Further economic research on the subject is necessary.

- $\quad$ The absence of studies on benefit transfer within the field of BFR. Given that numerous studies use the hedonic pricing method, we consider that there is sufficient scientific material to conduct a metaanalysis capable of producing a benefit transfer function. This would make it possible to predict the impact of a given BFR project on property values, taking into account a range of determining factors. This type of benefit transfer function could easily be used by researchers working on the development and application of sustainable assessment methods and tools. It would be a way of enhancing the link between the EL and SAL. 
Ameller, J., Rinaudo, J. D., \& Merly, C. (2020). The contribution of economic science to brownfield redevelopment: a review. Integrated Environmental Assessment and Management, 16(2), 184-196.

- $\quad$ Lastly, the absence of a holistic approach. Developing holistic approaches, by moving from single or limited economic evaluations (e.g. cost remediation, property value) to an economic assessment of the diverse direct and indirect benefits of BFR. This may require the use of a combination of economic tools.

\section{Gaps and directions for future research in $S A L$}

The SAL approach would also benefit from the above proposals for future R\&D. SAL is primarily based on decision support tools and Multi-Criteria Analysis, which are complementary. Two main developments can be envisaged for SA literature.

Appraisals of BFR projects call for a multidisciplinary approach. Indeed, Multi-Criteria Assessments (MCA) are the most widely used approach to help decision-making. However, complementing MCA with economic assessments (Cost-Efficiency and Cost-Benefit Analysis) would facilitate decision-making for BFR projects that have a high social value. Here, we agree with the findings presented by Bartke and Schwarze (2015): there is no perfect tool to suit all cases. Economic analyses (CBA \& CEA) provide insights into the economic aspects of BFR projects. Therefore, we argue that they are complementary to sustainable assessments.

In-depth BFR sustainability assessments are often conducted on a site-specific scale, whereas studies at a regional scale tend to prioritize different sites for BFR. However, in some cities, developers are faced with more complex situations with dozens of sites that need to be managed. Each site can be redeveloped according to several scenarios (future end-uses). In this context, we argue that there is scope for developing DST that are designed to identify solutions for a portfolio of sites (on a regional scale). This involves the development of optimization models capable of identifying which BFR projects (rehabilitation and future end-use) maximize social welfare. 
Ameller, J., Rinaudo, J. D., \& Merly, C. (2020). The contribution of economic science to brownfield redevelopment: a review. Integrated Environmental Assessment and Management, 16(2), 184-196.

\section{CONCLUSION}

In the coming decade, the decline in heavy industry in developed countries is likely to generate more brownfields. At the same time, society is increasingly demanding when it comes to environmental matters and no longer accepts the nuisances generated by these sites. While the problem is growing, available funds continue to be scarce. Policymakers are forced to maximize efficiency and promote private stakeholder involvement in BFR. This situation requires decision support tools that would allow an in-depth economic analysis of BFR (Nathanail et al. 2018).

In that context, it is essential to promote a greater integration of concepts and methods developed in isolation by different scientific groups. The SAL community is already familiar with interdisciplinary approaches. Therefore, it may be better placed to develop an integrated approach than is the case for economists. However, it is important to raise awareness about the diverse approaches developed by the many sub-disciplines of economics, what can they offer to stakeholders involved in BFR projects or policies, the issues can they address, at what scale, the methods they use and the data they require, etc. We hope that this paper and the associated database provided in supplemental material will provide a cornerstone to encourage a shift in BFR research. Additional efforts are required to break down the barriers between research fields. Public agencies have a responsibility when it comes to setting the research agenda at national, European and international level. Indeed, scientific societies that organize large conferences and individual researchers operating in the BFR field also have a responsibility.

\section{REFERENCES}

Adams D, Disberry A, Hutchison N, Munjoma T. 2000. Mind the gap! Taxes, subsidies and the behaviour of brownfield owners. Land use policy. 17(2):135-145. doi:10.1016/S0264-8377(00)00003-X.

Adams D, Disberry A, Hutchison N, Munjoma T. 2001. Ownership constraints to brownfield redevelopment. Environ Plan A. 33(3):453-477. doi:10.1068/a33200. 
Ameller, J., Rinaudo, J. D., \& Merly, C. (2020). The contribution of economic science to brownfield redevelopment: a review. Integrated Environmental Assessment and Management, 16(2), 184-196.

Adams D, De Sousa C, Tiesdell S. 2010. Brownfield Development: A Comparison of North American and British Approaches. Urban Stud. 47:75-104. doi:10.1177/0042098009346868.

Alberini A, Longo A, Tonin S, Trombetta F, Turvani M. 2005. The role of liability, regulation and economic incentives in brownfield remediation and redevelopment: evidence from surveys of developers. Reg Sci Urban Econ. 35(4):327-351.

Alberini A, Tonin S, Turvani M. 2007. Willingness to Pay for Contaminated Site Cleanup Policies: Evidence from a Conjoint Choice Study in Italy. Rev Econ Polit. 117(5):737-749. doi:10.3917/redp.175.0737.

Bardos P, Bone B, Boyle R, Ellis D, Evans F, Harries ND, Smith JWNN. 2011. Applying sustainable development principles to contaminated land management using the SuRF-UK framework. Remediation. 21(2):77-100. doi:10.1002/rem.20283.

Bardos RP, Bone BD, Boyle R, Evans F, Harries ND, Howard T, Smith JWN. 2016. The rationale for simple approaches for sustainability assessment and management in contaminated land practice. Sci Total Environ. 563-564:755-68. doi:10.1016/j.scitotenv.2015.12.001.

Bartke S. 2011. Valuation of market uncertainties for contaminated land. Int J Strateg Prop Manag. 15(4):356-378. doi:10.3846/1648715X.2011.633771.

Bartke S, Martinát S, Klusáček P, Pizzol L, Alexandrescu F, Frantál B, Critto A, Zabeo A. 2016. Targeted selection of brownfields from portfolios for sustainable regeneration: User experiences from five cases testing the Timbre Brownfield Prioritization Tool. J Environ Manage. 184:94-107. doi:10.1016/j.jenvman.2016.07.037.

Bartke S, Schwarze R. 2015. No perfect tools: Trade-offs of sustainability principles and user requirements in designing support tools for land-use decisions between greenfields and brownfields. J Environ Manage. 153:11-24. doi:10.1016/j.jenvman.2015.01.040.

Bartsch C, Wells B. 2003. Community Involvement in Brownfield Redevelopment. Northeast Midwest Institute, ....(March).

Beames A, Broekx S, Heijungs R, Lookman R, Boonen K, Van Geert Y, Dendoncker K, Seuntjens P. 2015. Accounting for land-use efficiency and temporal variations between brownfield remediation alternatives in life-cycle assessment. $\mathrm{J}$ Clean Prod. 101:109-117. doi:10.1016/J.JCLEPRO.2015.03.073.

BenDor TK, Metcalf SS, Paich M. 2011. The dynamics of brownfield redevelopment. Sustainability. 3(6):914-936. doi:10.3390/su3060914.

Blackman A, Darley S, Lyon TP, Wernstedt K. 2010. What Drives Participation in State Voluntary Cleanup Programs? Evidence from Oregon. Land Econ. 86(4):785-799. doi:10.1353/lde.2010.0010.

Blokhuis EGJ, Snijders CCP, Han Q, Schaefer WF. 2012. Conflicts and Cooperation in Brownfield Redevelopment Projects: Application of Conjoint Analysis and Game Theory to Model Strategic Decision Making. J Urban Plan Dev. 138(3):195-205. doi:10.1061/(ASCE)UP.1943-5444.0000122.

Carlon C, Critto A, Ramieri E, Marcomini A. 2007. DESYRE: Decision Support System for the Rehabilitation of Contaminated Megasites. Integr Environ Assess Manag. 3(2):211. doi:10.1897/IEAM_2006-007.1.

Chen I-C, Tsai Y-C, Ma H-W. 2016. Toward Sustainable Brownfield Redevelopment Using Life-Cycle Thinking. Sustainability. 8(12):994. doi:10.3390/su8100994.

Coffin SL, Shepherd A. 1998. Barriers to Brownfield Redevelopment: Lessons Learned from Two Great Lakes States. 
Ameller, J., Rinaudo, J. D., \& Merly, C. (2020). The contribution of economic science to brownfield redevelopment: a review. Integrated Environmental Assessment and Management, 16(2), 184-196.

Public Work Manag Policy. 2(3):258-266. doi:10.1177/1087724X9800200309.

Cooper HM. 1988. Organizing knowledge syntheses: A taxonomy of literature reviews. Knowl Soc. 1(1):104-126. doi:10.1007/BF03177550.

Critto A, Agostini P. 2009. Using multiple indices to evaluate scenarios for the remediation of contaminated land: The Porto Marghera (Venice, Italy) contaminated site. Environ Sci Pollut Res. 16(6):649-662. doi:10.1007/s11356-009-01945.

Damigos D, Kaliampakos D. 2003. Assessing the benefits of reclaiming urban quarries: a CVM analysis. Landsc Urban Plan. 64(4):249-258.

Day SJ, Morse GK, Lester JN. 1997. The cost effectiveness of contaminated land remediation stategies. Sci Total Environ. 201(2):125-136. doi:10.1016/S0048-9697(97)00097-1.

Döberl G, Ortmann M, Frühwirth W. 2013. Introducing a goal-oriented sustainability assessment method to support decision making in contaminated site management. Environ Sci Policy. 25:207-217. doi:10.1016/J.ENVSCI.2012.10.013.

Doick KJ, Pediaditi K, Moffat AJ, Hutchings TR. 2009. Defining the Sustainability Objectives of Brownfield Regeneration To Greenspace. Int J Manag Decis Mak. 10(3/4):282-302. doi:10.1504/IJMDM.2009.024994.

EC. 2012. The implementation of the Soil Thematic Strategy and ongoing activities. 13 February European Commission, Brussels.

Eckerd A, Heidelberg RL. 2015. Public incentives, market motivations, and contaminated properties: New public management and brownfield liability reform. Public Adm Rev. 75(2):252-261. doi:10.1111/puar.12305.

EEA. 2018. Europe's environment : the second assessment. Eur Environ Agency.

Farber S. 1998. Undesirable facilities and property values: A summary of empirical studies. Ecol Econ. 24(1):1-14. doi:10.1016/S0921-8009(97)00038-4.

Gayer T, Hamilton JT, Viscusi WK. 2000. Private Values of Risk Tradeoffs at Superfund Sites: Housing Market Evidence on Learning about Risk. Rev Econ Stat. 82(3):439-451. doi:10.2307/2646804.

Glumac B, Blokhuis EGJ, Han Q. 2011. Decision making in real estate development: application of game theory. SerVicE_Magazine. 18(3):26-30.

Glumac B, Han Q, Schaefer W, van der Krabben E. 2015. Negotiation issues in forming public-private partnerships for brownfield redevelopment: Applying a game theoretical experiment. Land use policy. 47:66-77. doi:10.1016/j.landusepol.2015.03.018.

Gomez-Navarro T, Garcia-Melon M. 2011. DESIGN OF AN EFFICIENCY INDEX FOR THE RANK ORDER OF SOIL REMEDIATION TECHNIQUES. Environ Eng Manag. 10(5):603-613.

Hanley N. 2001. Cost-benefit analysis and environmental policymaking. Environ Plan C-Government Policy. 19(1):103118. doi:10.1068/c3s.

Hou D, Al-Tabbaa A. 2014. Sustainability: A new imperative in contaminated land remediation. Environ Sci Policy. 39:25-34. doi:https://doi.org/10.1016/j.envsci.2014.02.003.

Hunt M. 1997. How science takes stock: The story of meta-analysis. Russell Sage Found. 
Ameller, J., Rinaudo, J. D., \& Merly, C. (2020). The contribution of economic science to brownfield redevelopment: a review. Integrated Environmental Assessment and Management, 16(2), 184-196.

Huysegoms L, Cappuyns V. 2017. Critical review of decision support tools for sustainability assessment of site remediation options. J Environ Manage. 196:278-296. doi:10.1016/j.jenvman.2017.03.002.

Huysegoms L, Rousseau S, Cappuyns V. 2018. Friends or foes? Monetized Life Cycle Assessment and Cost-Benefit Analysis of the site remediation of a former gas plant. Sci Total Environ. 619-620:258-271. doi:10.1016/J.SCITOTENV.2017.10.330.

Jenkins R, Kopits E, Simpson D. 2006. Measuring the Social Benefits of EPA Land Cleanup and Working Paper Series National Center for Environmental Economics Measuring the Social Benefits of EPA Land Cleanup and Reuse Programs Correspondence :

Lavee D, Ash T, Baniad G. 2012. Cost-benefit analysis of soil remediation in Israeli industrial zones. Nat Resour Forum. 36(4):285-299. doi:10.1111/j.1477-8947.2012.01462.x.

Leigh NG, Coffin SL. 2000. How Many Brownfields Are There? Building an Industrial Legacy Database. J Urban Technol. 7(3):1-18. doi:10.1080/713684132.

Lesage P, Ekvall T, Deschenes L, Samson R. 2007. Environmental assessment of Brownfield rehabilitation using two different life cycle inventory models. Int J Life Cycle Assess. 12(6):391-398. doi:10.1065/lca2006.10.279.1.

Li J, Rahman MH, Thring RW. 2010. A fuzzy multi-criteria decision analysis approach for the management of petroleumcontaminated sites. Int J Environ Pollut. 42(1/2/3):220. doi:10.1504/IJEP.2010.034236.

Lin H, Zhu Y, Ahmad N, Han Q. 2019. A scientometric analysis and visualization of global research on brownfields. Environ Sci Pollut Res. 26(17):17666-17684. doi:10.1007/s11356-019-05149-3.

Longo A, Alberini A. 2006. What are the effects of contamination risks on commercial and industrial properties? Evidence from Baltimore, Maryland. J Environ Plan Manag. 49(5):713-737. doi:10.1080/09640560600850028.

Mashayekh Y, Hendrickson C, Matthews HS. 2012. Role of Brownfield Developments in Reducing Household Vehicle Travel. J Urban Plan Dev. 138(3):206-214. doi:10.1061/(ASCE)UP.1943-5444.0000113.

Nathanail CP, Boekhold AE, Grimski D, Bartke S. 2018. The Europeans' Strategic Research Agenda for Integrated Spatial Planning, Land Use and Soil Management. Dessau-Roßlau, Germany.

Neupane A, Gustavson K. 2008. Urban property values and contaminated sites: A hedonic analysis of Sydney, Nova Scotia. J Environ Manage. 88(4):1212-1220. doi:10.1016/J.JENVMAN.2007.06.006.

Oliver L, Millar K, Grimski D, Ferber U, Nathanail P. 2005. The scale and nature of european brownfields. In: Proceedings of CABERNET: The international conference on Managing Urban Land. Nottingham: Land Quality Press. p. 274-281.

Palmquist RB. 1984. Estimating the Demand for Characteristics of Housing. Rev Econ Stat. 66(3):394-404. doi:10.2307/1924995.

Panagos P, Van Liedekerke M, Yigini Y, Montanarella L. 2013. Contaminated sites in Europe: Review of the current situation based on data collected through a European network. J Environ Public Health. 2013:158764. doi:10.1155/2013/158764.

Paull E. 2008. The Environmental and Econonic Impacts of Brownfields Redevelopment. Northeast Institute, Washington, DC.:1-53. 
Ameller, J., Rinaudo, J. D., \& Merly, C. (2020). The contribution of economic science to brownfield redevelopment: a review. Integrated Environmental Assessment and Management, 16(2), 184-196.

Payá Pérez A, Rodríguez Eugenio N. 2018. Status of local soil contamination in Europe: Revision of the indicator "Progress in the management Contaminated Sites in Europe. Luxembourg.

Pediaditi K, Doick KJ, Moffat AJ. 2010. Monitoring and evaluation practice for brownfield, regeneration to greenspace initiatives. A meta-evaluation of assessment and monitoring tools. Landsc Urban Plan. 97(1):22-36. doi:10.1016/j.landurbplan.2010.04.007.

Pizzol L, Zabeo A, Klusáček P, Giubilato E, Critto A, Frantál B, Martinát S, Kunc J, Osman R, Bartke S. 2016. Timbre Brownfield Prioritization Tool to support effective brownfield regeneration. J Environ Manage. 166(166):178-192. doi:10.1016/j.jenvman.2015.09.030.

Rinaudo J-D, Aulong S. 2014. Defining Groundwater Remediation Objectives with Cost-benefit Analysis: Does It Work? Water Resour Manag. 28(1):261-278. doi:10.1007/s11269-013-0483-0.

Rinaudo JD, Loubier S. 2005. Cost-benefit analysis of large scale groundwater remediation in France. In: Cost Benefit Analaysis and Water Resources Management. Cheltenham: Edward Elgar Publisher. p. 290-314.

Rizzo E, Pesce M, Pizzol L, Alexandrescu. FM, Giubilato E, Critto A, Marcomini A, Bartke S. 2015. Brownfield regeneration in Europe: Identifying stakeholder perceptions, concerns, attitudes and information needs. Land use policy. 48:437-453. doi:10.1016/j.landusepol.2015.06.012.

Rosén L, Back P-E, Söderqvist T, Norrman J, Brinkhoff P, Norberg T, Volchko Y, Norin M, Bergknut M, Döberl G. 2015. SCORE: A novel multi-criteria decision analysis approach to assessing the sustainability of contaminated land remediation. Sci Total Environ. 511:621-638. doi:10.1016/J.SCITOTENV.2014.12.058.

Samsura DAA, van der Krabben E, van Deemen AMAA. 2010. A game theory approach to the analysis of land and property development processes. Land use policy. 27(2):564-578. doi:10.1016/j.landusepol.2009.07.012.

Schädler S, Morio M, Bartke S, Finkel M. 2012. Integrated planning and spatial evaluation of megasite remediation and reuse options. J Contam Hydrol. 127(1-4):88-100. doi:10.1016/j.jconhyd.2011.03.003.

Schadler S, Morio M, Bartke S, Rohr-Z??nker R, Finkel M. 2011. Designing sustainable and economically attractives brownfield revitalization options using an integrated assessment model. J Environ Manage. 92(3):827-837. doi:10.1016/j.jenvman.2010.10.026.

Simmons RA. 1998. Turning Brownfields Into Greenfields. Urban L Institute, Washington, DC.

Simons R a., Saginor J. 2010. Determining Off-Site Damages to Non-Residential Property from Leaking Underground Storage Tanks Using Contingent Valuation Analysis. Int Real Estate Rev. 13:134-156.

Simons R a., Winson-Geideman K. 2005. Determining market perceptions on contamination of residential property buyers using contingent valuation surveys. J Real Estate Res. 27(2):193-220.

Söderqvist T, Brinkhoff P, Norberg T, Rosén L, Back P-E, Norrman J. 2015. Cost-benefit analysis as a part of sustainability assessment of remediation alternatives for contaminated land. J Environ Manage. 157:267-278. doi:10.1016/J.JENVMAN.2015.04.024.

Song Y, Hou D, Zhang J, O’Connor D, Li G, Gu Q, Li S, Liu P. 2018. Environmental and socio-economic sustainability appraisal of contaminated land remediation strategies: A case study at a mega-site in China. Sci Total Environ. 610611:391-401. doi:10.1016/J.SCITOTENV.2017.08.016.

Sorvari J, Seppälä J. 2010. A decision support tool to prioritize risk management options for contaminated sites. Sci Total 
Ameller, J., Rinaudo, J. D., \& Merly, C. (2020). The contribution of economic science to brownfield redevelopment: a review. Integrated Environmental Assessment and Management, 16(2), 184-196.

Environ. 408(8):1786-1799. doi:https://doi.org/10.1016/j.scitotenv.2009.12.026.

De Sousa CA. 2002. Measuring the public costs and benefits of brownfield versus greenfield development in the Greater Toronto area. Environ Plan B Plan Des. 29(2):251-280. doi:10.1068/b1283.

De Sousa CA. 2003. Turning brownfields into green space in the City of Toronto. Landsc Urban Plan. 62(4):181-198. doi:10.1016/S0169-2046(02)00149-4.

De Sousa CA. 2004. The greening of brownfields in American cities. J Environ Plan Manag. 47(4):579-600. doi:10.1080/0964056042000243249.

Spiess T, De Sousa C. 2016. Barriers to Renewable Energy Development on Brownfields. J Environ Policy Plan. 18(4):507-534. doi:10.1080/1523908X.2016.1146986.

Strazzera E, Cherchi E, Ferrini S. 2010. Assessment of regeneration projects in urban areas of environmental interest: A stated choice approach to estimate use and quasi-option values. Environ Plan A. 42(2):452-468. doi:10.1068/a4213.

Turvani M, Tonin S. 2008. Brownfields remediation and reuse: An opportunity for urban sustainable development. Sustain Dev Environ Manag Exp Case Stud.:397-411. doi:10.1007/978-1-4020-8229-0_28.

Tyrväinen L, Väänänen H. 1998. The economic value of urban forest amenities: an application of the contingent valuation method. Landsc Urban Plan. 43(1-3):105-118. doi:10.1016/S0169-2046(98)00103-0.

U.S. EPA. 2016. Superfund: National Priorities List (NPL).

U.S. EPA. 2017. State Brownfield and Voluntary Response Programs.

Volchko Y, Norrman J, Rosén L, Karlfeldt Fedje K. 2017. Cost-benefit analysis of copper recovery in remediation projects: A case study from Sweden. Sci Total Environ. 605-606:300-314. doi:10.1016/J.SCITOTENV.2017.06.128.

Walker SB, Boutilier T, Hipel KW. 2010. Systems Management Study of a Private Brownfield Renovation. J Urban Plan Dev. 136(3):249-260. doi:10.1061/(ASCE)0733-9488(2010)136:3(249).

Webster J, Watson RT. 2002. Analyzing the past to prepare for the future: Writing a literature review Reproduced with permission of the copyright owner . Further reproduction prohibited without permission . MIS Q. 26(2):xiii-xxiii. doi: $10.2307 / 4132319$.

Wedding GC, Crawford-Brown D. 2007. Measuring site-level success in brownfield redevelopments: A focus on sustainability and green building. J Environ Manage. 85(2):483-495. doi:10.1016/j.jenvman.2006.10.018.

Wernstedt K, Meyer PB, Alberini A, Heberle L. 2006. Incentives for private residential brownfields development in US urban areas. J Environ Plan Manag. 49(1):101-119. doi:10.1080/09640560500373212.

Whitney H. 2003. Cities and superfund: Encouraging brownfield redevelopment. Ecol Law Q. 30(1):59-112. doi:10.15779/Z381C3S.

Yousefi S, Hipel KW, Hegazy T. 2010. Considering Attitudes in Strategic Negotiation over Brownfield Disputes. J Leg Aff Disput Resolut Eng Constr. 2:240-247. doi:doi:10.1061/(ASCE)LA.1943-4170.0000034.

Yousefi S, Hipel KW, Hegazy T, Witmer JA, Gray P. 2007. Negotiation characteristics in brownfield redevelopment projects. In: Conference Proceedings - IEEE International Conference on Systems, Man and Cybernetics. IEEE. p. 18661871. 


\section{This is a pre-print version of :}

Ameller, J., Rinaudo, J. D., \& Merly, C. (2020). The contribution of economic science to brownfield redevelopment: a review. Integrated Environmental Assessment and Management, 16(2), 184-196. 
Ameller, J., Rinaudo, J. D., \& Merly, C. (2020). The contribution of economic science to brownfield redevelopment: a review. Integrated Environmental Assessment and Management, 16(2), 184-196.

\section{LIST OF FIGURES}

Figure 1: Groups of keywords used to identify the targeted literature and number of papers identified with successive combinations of keywords. . .8

Figure 2: Main benefits of brownfield redevelopment 14

Figure 3. Analysis of EL \& SAL .27

Figure captions in editable text:

Figure 1: Groups of keywords used to identify the targeted literature and number of papers identified with successive combinations of keywords

Figure 2: Main benefits of brownfield redevelopment

Figure 3. Analysis of EL \& SAL 